\title{
STUDI PENYEBARAN KLOROFIL-A, SUHU PERMUKAAN LAUT DAN ANGIN UNTUK IDENTIFIKASI UPWELLING DI PERAIRAN SELATAN SUMBAWA TAHUN 2018
}

\author{
Agus Setianto, Kostansa Tri Adinda Witomo, Muhammad Hizrian Irda dan \\ Ika Kurnia Putri
}

Departemen Lingkungan, PT Amman Mineral Nusa Tenggara

\begin{abstract}
ABSTRAK
Perairan Selatan Sumbawa merupakan perairan terbuka yang langsung berhadapan dengan Samudera Hindia sehingga karakteristik perairannya menjadi sangat dinamis. Operasional pertambangan PTAMNT menghasilkan tailing (sisa batuan) yang ditempatkan di Ngarai Senunu Perairan Selatan Sumbawa pada kedalaman $125 \mathrm{~m}$ di bawah permukaan laut. Untuk memastikan operasional penempatan tailing berjalan dengan baik maka diperlukan pemantauan laut secara rutin dan teratur termasuk salah satunya pemantauan upwelling di sekitar wilayah penempatan tailing. Hasil studi ini menunjukkan bahwa fenomena upwelling di Perairan Selatan Sumbawa khususnya di sekitar penempatan tailing PTAMNT berdasarkan suhu permukaan laut sangat kuat terjadi pada bulan Juni hingga September dengan puncak kekuatan upwelling tertinggi terjadi pada bulan Juli (rata-rata suhu permukaan laut terendah $25,64{ }^{\circ} \mathrm{C}$ ) dan fenomena upwelling berdasarkan klorofil-a sangat kuat terjadi pada bulan April hingga Juni dengan puncak kekuatan kriteria upwelling tertinggi terjadi pada bulan Juni (rata-rata klorofil-a tertinggi $1,01 \mathrm{mg} / \mathrm{m}^{3}$ ). Sedangkan fenomena downwelling berdasarkan suhu permukaan laut terjadi pada bulan Desember (rata-rata suhu permukaan laut tertinggi $28,84{ }^{\circ} \mathrm{C}$ ) dan fenomena downwelling berdasarkan klorofil-a terjadi juga pada bulan Desember (rata-rata klorofil-a terendah $0,14 \mathrm{mg} / \mathrm{m}^{3}$ ). Hasil studi ini juga menunjukan bahwa selama periode upwelling di Perairan Selatan Sumbawa khususnya di sekitar penempatan tailing PTAMNT tidak memperlihatkan adanya indikasi naiknya atau munculnya tailing ke lapisan permukaan.
\end{abstract}

Kata kunci: Angin, Klorofil-a, Suhu Permukaan Laut, Upwelling \& Tailing

\begin{abstract}
South Sumbawa Waters are open waters that comes straight to the Indian Ocean so the characteristic of the waters becomes very dynamic. Mining operation of PTAMNT produce tailings (remnants of rocks) that placed in Senunu Canyon at South Sumbawa Waters at $125 \mathrm{~m}$ depth under sea surface. To ensure proper process of tailing placement, regular monitoring is needed including upwelling monitoring around tailing placement area. The result of this study shows that South Sumbawa Waters especially PTAMNT tailing placement area, very strong upwelling characteristic based on sea surface temperature occurred on June - September with July as the peak (lowest average temp $25,64{ }^{\circ} \mathrm{C}$ ) and very strong upwelling characteristic based chlorophyll-a occurred on April - June with June as the peak (highest average chlorophyll-a 1,01 $\mathrm{mg} / \mathrm{m}^{3}$ ). Meanwhile, downwelling characteristic based on sea surface temperature occurred on December (highest average temp 28,84 ${ }^{\circ} \mathrm{C}$ ) and downwelling characteristic based on chlorophyll-a occurred on December (lowest average chlorophyll-a $0,14 \mathrm{mg} / \mathrm{m}^{3}$ ). The result of this study during upwelling period in South Sumbawa Waters especially PTAMNT tailing placement area also did not shows any indication of the rise or appearance of tailings to sea surface.
\end{abstract}

Keywords: Wind, Chlophyll-a, Sea Surface Temperature, Upwelling \& Tailing 


\section{A. PENDAHULUAN}

Perairan Selatan Sumbawa merupakan perairan terbuka yang langsung berhadapan dengan Samudera Hindia sehingga karakteristik perairannya menjadi sangat dinamis. Operasional pertambangan PTAMNT menghasilkan tailing (sisa batuan) yang ditempatkan di Ngarai Senunu Perairan Selatan Sumbawa pada kedalaman $125 \mathrm{~m}$ dibawah permukaan laut. PTAMNT adalah perusahaan pertambangan tembaga - emas yang berada di Pulau Sumbawa tepatnya di Kabupaten Sumbawa Barat (KSB), dimana lokasi penempatan tailing-nya berada di Perairan Selatan Sumbawa yang merupakan bagian dari Samudera Hindia. Pada makalah ini membahas tentang fenomena upwelling di Perairan Selatan Sumbawa dimana upwelling didefinisikan sebagai proses naiknya massa air dari lapisan bawah ke lapisan yang berada diatasnya yang banyak membawa nutrien. Proses ini menyebabkan suhu permukaan laut lebih rendah dari sekitarnya, dan naiknya unsur zat hara ke permukaan sangat dibutuhkan oleh biota (ikan) sebagai bahan makanan (Hasyim, 2014). Muatan unsur hara yang tinggi dapat merangsang pertumbuhan fitoplankton sebagai pakan alami ikan. Keberadaan fitoplankton dapat diketahui dari kandungan klorofil-a dan suhu permukaan laut (SPL) melalui kegiatan pemantauan laut secara langsung di lapangan dengan cara melakukan pengukuran profil kolom air laut dengan menggunakan peralatan ukur seperti CTD (Conductivity, Depth \& Temperature) serta menggunakan data arah dan kecepatan angin. Penggabungan penggunaan teknologi alat ukur kolom air laut (CTD) serta alat pengukur meteorologi diharapkan dapat memberikan informasi serta dapat dijadikan database dalam mengidentifikasi upwelling dalam kaitannya dengan operasional penempatan tailing di wilayah pertambangan PTAMNT.

\section{B. METODOLOGI}

\section{B.1. Waktu dan Lokasi}

Pengambilan data dilakukan di Perairan Selatan Sumbawa selama periode Januari - Desember 2018 di dua puluh stasiun dengan menggunakan kapal survey Tenggara Ranger. Pengolahan dan analisa data dilakukan di Department Safety, Heatlh \& Environmental PTAMNT.

\section{B.2. Metode Pengumpulan \& Pengolahan Data}

Data suhu permukaan air laut dan klorofil-a yang digunakan merupakan data yang langsung diperoleh dari lapangan melalui alat ukur CTD SBE911 (SBE: Sea Bird Electronic) melalui program SeaSave7 dan di konversi menjadi excel files menggunakan program SBE DataProcessing. Data arah dan kecepatan angin yang digunakan merupakan rata-rata harian dengan interval 10 menit yang diperoleh dari satu stasiun cuaca kemudian diolah melalui program MS. Excel.

\section{B.3. Metode Analisa Sebaran, Grafik dan Diagram}

Analisa data suhu permukaan air laut dan klorofil-a dilakukan dengan melihat sebaran horizontal untuk setiap parameter. Hasil sebaran tersebut di analisa untuk melihat distribusi atau penyebaran suatu parameter di suatu perairan. Dalam proses pembuatan sebaran dilakukan beberapa tahapan antara lain:

1. Proses pembuatan grafik multitemporal dan kriteria kekuatan upwelling berdasarkan suhu permukaan air laut dan klorofil-a dilakukan dengan menggunakan program MS. Excel.

2. Proses pembuatan sebaran horizontal dilakukan dengan menggunakan program Surfer13.

3. Proses pembuatan grafik Wind Chart untuk melihat pola arah \& kecepatan angin dilakukan dengan menggunakan program Grapher11.

\section{HASIL DAN PEMBAHASAN}

\section{C.1 Upwelling Berdasarkan Pola Musim}

Parameter klorofil-a dan suhu permukaan laut serta pola sebaran angin di suatu perairan sangat mempengaruhi terjadinya fenomena upwelling. Dalam studi ini menitikberatkan pada musim barat 
yang diwakili oleh bulan Oktober - Desember serta musim timur yang diwakili oleh bulan Juni Agustus.

Tabel 1 di bawah terlihat bahwa pada musim timur, nilai rata-rata klorofil-a tertinggi sebesar 1,01 $\mathrm{mg} / \mathrm{m}^{3}$ yang terjadi pada bulan Juni, nilai rata-rata suhu permukaan laut terendah sebesar $25,64{ }^{0} \mathrm{C}$ yang terjadi pada bulan Juli dan nilai rata-rata kecepatan angin mencapai nilai maksimum sebesar $3,12 \mathrm{~m} / \mathrm{s}$ juga terjadi pada bulan Juli.

Tabel 1. Nilai Sebaran Rata-rata Klorofil-a, SPL dan Kecepatan Angin Tahun 2018

\begin{tabular}{cccc}
\hline Bulan & Klorofil-a $\left(\mathbf{m g} / \mathbf{m}^{\mathbf{3}}\right)$ & SPL $(\mathbf{d e g} \mathbf{C})$ & Kec. Angin $\mathbf{( m / s )}$ \\
\hline Januri & 0.20 & 28.67 & 1.88 \\
Februari & 0.21 & 28.03 & 1.55 \\
Maret & 0.55 & 28.18 & 1.85 \\
April & 0.83 & 28.49 & 2.15 \\
Mei & 0.92 & 27.40 & 3.12 \\
Juni & $\mathbf{1 . 0 1}$ & 26.31 & 2.93 \\
Juli & 0.57 & $\mathbf{2 5 . 6 4}$ & $\mathbf{3 . 1 2}$ \\
Agustus & 0.44 & 26.08 & 2.71 \\
September & 0.30 & 25.79 & 2.30 \\
Oktober & 0.26 & 26.98 & 1.89 \\
November & 0.23 & 28.04 & 1.68 \\
Desember & 0.14 & 28.84 & 1.58 \\
\hline
\end{tabular}

Hal berbeda ketika memasuki musim barat, dimana nilai rata-rata klorofil-a terendah sebesar 0,14 $\mathrm{mg} / \mathrm{m}^{3}$, nilai rata-rata suhu permukaan laut sebesar $28,84{ }^{\circ} \mathrm{C}$ dan nilai rata-rata kecepatan angin yang relatif rendah sebesar $1,58 \mathrm{~m} / \mathrm{s}$ yang terjadi juga pada bulan Desember.

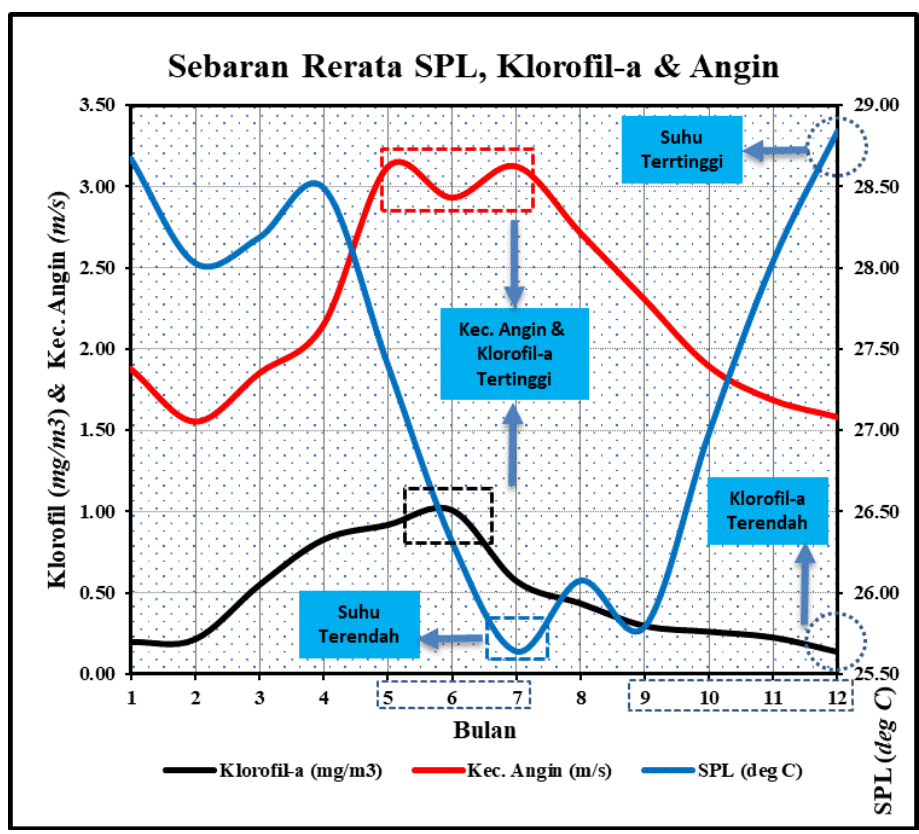

Gambar 1. Grafik Multitemporal Klorofil-a, SPL dan Kecepatan Angin Tahun 2018

Grafik multitemporal di atas menunjukkan hubungan antara klorofil-a dengan kecepatan angin berbanding lurus namun berbanding terbalik dengan suhu permukaan laut. Hal tersebut terlihat saat nilai klorofil-a dan kecepatan angin mencapai maksimum terjadi pada musim timur (Juni) namun berbanding terbalik dengan suhu permukaan laut yang rendah pada musim timur (Juli). Hal berbeda ketika memasuki musim barat, dimana sebaran klorofil-a dan kecepatan angin mencapai nilai terendah terjadi pada bulan Desember dengan sebaran suhu permukaan laut mencapai titik tertinggi. Perubahan di atas tidak terlepas dari pola sebaran angin di Perairan Selatan Sumbawa 
selama bulan Januari - Desember 2018. Hal tersebut dapat terlihat pada gambar wind chart di bawah ini.

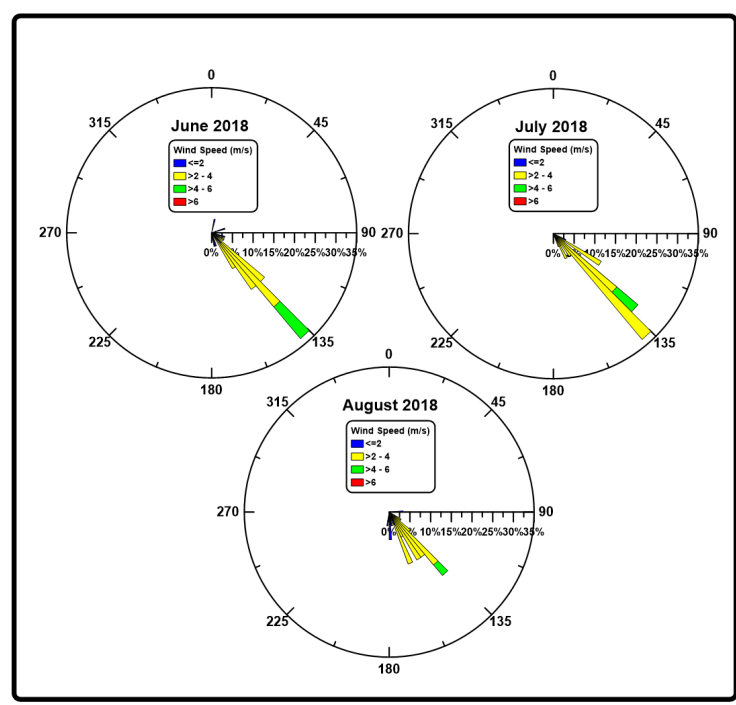

(a)

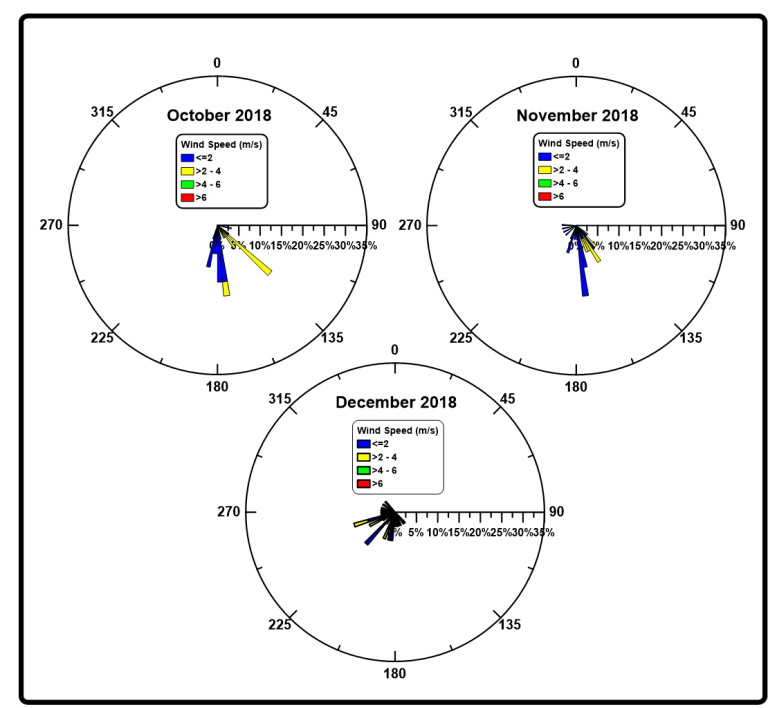

(b)

Gambar 2. Pola Sebaran Angin di Perairan Selatan Sumbawa Musim Timur (a) dan Musim Barat (b), Tahun 2018

Gambar wind chart di atas merupakan pola sebaran arah dan kecepatan angin pada musim timur yang diwakili oleh bulan Juni - Agustus. Gambar tersebut memperlihatkan pergerakan angin yang relatif sama dimana angin bergerak dari arah Tenggara (Benua Australia) menuju arah Barat Laut (Benua Asia) yang melewati Perairan Indonesia yang salah satunya adalah Perairan Selatan Sumbawa. Pergerakan angin tersebut dikarenakan pada musim timur posisi matahari berada di belahan bumi utara khususnya di Benua Asia, dimana memiliki suhu udara yang tinggi dan tekanan udara yang rendah. Sebaliknya di Benua Australia yang berada dibelahan bumi selatan mengalami penurunan suhu udara namun memiliki tekanan udara yang tinggi. Perbedaan tekanan udara inilah yang menyebabkan angin bergerak dari Benua Australia menuju Benua Asia melewati Indonesia. Pergerakan angin ini sedikit membawa uap air atau tidak menurunkan hujan dikarenakan angin ini hanya melawati beberapa laut kecil \& sempit seperti Laut Timor, Laut Sawu dan beberapa Perairan Nusa Tenggara. Namun kecepatan angin pada musim timur mencapai puncaknya pada bulan Juli sebesar $3,12 \mathrm{~m} / \mathrm{s}$ dan mengalami penurunan pada bulan Agustus sebesar 2,71 m/s. Pola sebaran angin mengalami perubahan yang signifikan ketika memasuki musim barat, dimana pergerakan angin cenderung berubah dan tidak beraturan pada bulan Oktober hingga Desember. Hal ini dikarenakan posisi matahari berada di belahan bumi selatan khususnya di Benua Australia dimana memiliki suhu udara yang tinggi dan tekanan udara yang rendah. Sebaliknya di Benua Asia yang berada dibelahan bumi utara mengalami penurunan suhu udara namun memiliki tekanan udara yang tinggi. Perbedaan tekanan udara inilah yang menyebabkan angin bergerak dari Benua Asia menuju Benua Australia melewati Indonesia. Pergerakan angin ini banyak membawa uap air atau banyak menurunkan hujan khususnya di Indonesia bagian barat, hal ini terjadi dikarenakan angin melawati Samudera Pasifik, Samudera Hindia dan Laut Cina Selatan. Namun kecepatan angin pada musim barat mengalami penurunan jika dibandingkan dengan musim timur. Kecepatan angin mulai menurun terlihat pada bulan Oktober sebesar $1,89 \mathrm{~m} / \mathrm{s}$, bulan November sebesar $1,68 \mathrm{~m} / \mathrm{s}$ dan puncaknya pada bulan Desember sebesar $1,57 \mathrm{~m} / \mathrm{s}$.

\section{C.2. Kriteria Upwelling}

Kriteria upwelling dikelompokan menjadi Downwelling, Upwelling Menengah, Upwelling Kuat dan Upwelling Sangat Kuat (Kunarso, 2014). Gambar 3 di bawah memperlihatkan pola serta kriteria kekuatan upwelling berdasarkan suhu permukaan laut (SPL) di Perairan Selatan Sumbawa selama tahun 2018. Pada bulan Januari hingga April menunjukkan kriteria UM, kemudian pada bulan Mei menujukkan kriteria upwelling kuat dan kriteria upwelling sangat kuat terjadi pada bulan 
Juni hingga September dengan puncak kekuatan kriteria upwelling tertinggi terjadi pada bulan Juli (SPL terendah, 25,64 ${ }^{\circ} \mathrm{C}$ ). Namun saat memasuki bulan Oktober, kriteria upwelling mengalami penurunan menjadi kriteria upwelling kuat hingga downwelling yang terjadi pada bulan Desember (SPL tertinggi, $28,84{ }^{\circ} \mathrm{C}$ ). Puncak kriteria upwelling berdasarkan SPL sangat kuat (Juli) merupakan kondisi yang terjadi pada musim timur, namun sebaliknya kriteria downwelling terjadi pada bulan Desember (musim barat). Kondisi ini tidak terlepas dari pola angin yang terjadi di Indonesia dimana pada musim timur (Juli) pergerakan angin di mulai dari arah Tenggara menuju arah Barat Laut melewati Indonesia (Perairan Selatan Sumbawa) yang membawa suhu udara rendah (dingin, $\left.25,64{ }^{\circ} \mathrm{C}\right)$. Namun

sebaliknya pada musim barat (Desember) pergerakan angin di mulai dari arah Barat Laut menuju arah Tenggara melewati Indonesia (Perairan Selatan Sumbawa) yang membawa suhu udara tinggi (hangat, $28,84{ }^{\circ} \mathrm{C}$ ).

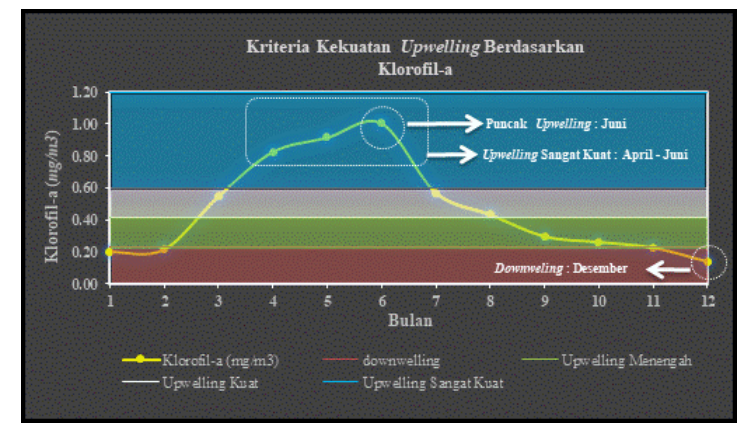

(a)

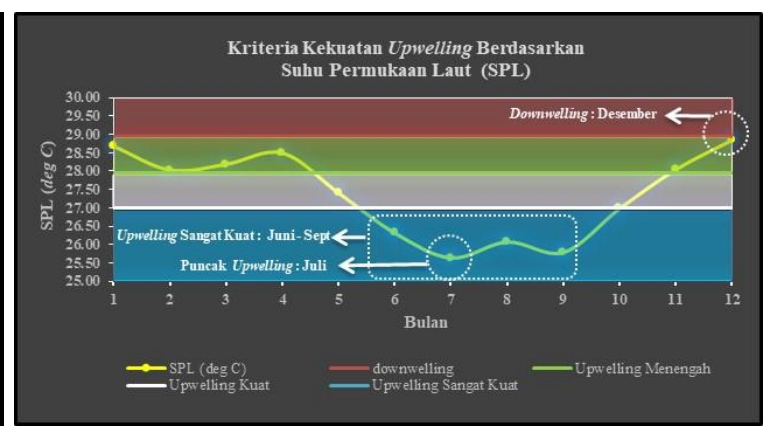

(b)

Gambar 3. Kriteria Kekuatan Upwelling berdasarkan Suhu Permukaan Laut $\left({ }^{0} \mathrm{C}\right)$ (a) dan Klorofil-a $\left(\mathrm{mg} / \mathrm{m}^{3}\right)(\mathrm{b})$, Tahun 2018

Gambar 3 di atas juga memperlihatkan pola serta kriteria kekuatan upwelling berdasarkan klorofil-a di Perairan Selatan Sumbawa selama tahun 2018. Pada bulan Januari hingga Februari menunjukkan kriteria downwelling, kemudian pada bulan Maret menujukkan kriteria upwelling kuat dan kriteria upwelling sangat kuat terjadi pada bulan April hingga Juni dengan puncak kekuatan kriteria upwelling tertinggi terjadi pada bulan Juni (klorofil-a tertinggi, $1,01 \mathrm{mg} / \mathrm{m}^{3}$ ). Namun saat memasuki bulan Juli, kriteria upwelling mengalami penurunan menjadi kriteria upwelling kuat hingga kriteria downwelling yang terjadi pada bulan Desember (klorofil-a terendah, $0,14 \mathrm{mg} / \mathrm{m}^{3}$ ). Puncak kriteria upwelling sangat kuat terjadi pada bulan Juni (musim timur), namun sebaliknya kriteria downwelling terjadi pada bulan Desember (musim barat). Kondisi ini tidak terlepas dari pola angin yang terjadi di Indonesia, dimana pada musim timur pergerakan angin di mulai dari arah Tenggara menuju arah Barat Laut melewati Indonsia (Perairan Selatan Sumbawa) yang memiliki kisaran kecepatan angin maksimum 2,93 m/s - 3,12 m/s yang terjadi pada bulan Juni - Juli. Namun sebaliknya pada musim barat pergerakan angin di mulai dari arah Barat Laut menuju arah Tenggara melewati Indonesia (Perairan Selatan Sumbawa) yang memiliki kecepatan angin minimum 1,58 $\mathrm{m} / \mathrm{s}$ yang terjadi pada bulan Desember.

Kecepatan angin maksimum yang berhembus di atas permukaan laut pada bulan Juni - Juli (musim timur) mendorong massa air laut yang berada di atas permukaan sehingga mengakibatkan kekosongan massa air, selanjutnya massa air yang berada di bawah lapisan permukaan akan mengisi kekosongan tersebut. Pergerakan massa air yang naik ke permukaan ini akan membawa suhu yang lebih dingin serta banyak membawa nutrien. Pergerakan massa air laut ini merupakan fenomena upwelling yang terjadi di Perairan Selatan Sumbawa, dimana kriteria kekuatan upwelling sangat kuat terjadi pada musim timur (Juni - Juli). Namun sebaliknya, kriteria kekuatan downwelling terjadi pada musim barat (Desember). 


\section{C.3. Uji Statistik}

Studi ini juga melakukan uji statistik, dimana uji statistik ini menggunakan metode The Rank Correlation Test (Korelasi Peringkat Spearman, Spearman 1904) (Raharjo, 2015). Metode ini digunakan untuk mengetahui atau mengukur keeratan atau keterkaitan hubungan antara dua variable yang berbeda. Hasil uji statistik ini akan memperlihatkan atau membuktikan apakah ada hubungan yang berbanding lurus atau berbanding terbalik antara SPL, klorofil-a dan angin. Kriteria keterkaitan hubungan antar variabel ini ditandai dengan koefisien korelasi $\left(R_{s}\right)$ yang berkisar antara \pm 1 dan \pm 0 . Dimana tanda ' + ' positive diartikan hubungan antar variabel berbanding lurus dan tanda '-" negative diartikan hubungan antar variabel berbanding terbalik. Berikut formula untuk mencari nilai koefisien korelasi antar variabel yang berbeda. Koefisien korelasi Spearman $\left(\mathrm{r}_{\mathrm{s}}\right)$ dirumuskan:

Keterangan :

$$
r_{s}=R_{\text {rank }}=1-\frac{6 \sum d_{i}^{2}}{n\left(n^{2}-1\right)}
$$

$\mathrm{d}_{\mathrm{i}} \quad$ : selisih dari pasangan rank ke i

n : banyaknya pasangan rank

Perhitungan dalam pencarian nilai koefisien korelasi menggunakan data pada tabel 1 di atas. Hasil perhitungan koefisien korelasi pada studi ini dapat dilihat pada tabel 2 di bawah ini.

Tabel 2. Hasil Uji Korelasi Spearman Klorofil-a, Suhu Permukaan dan Kecepatan Angin

\begin{tabular}{cccc}
\hline Korelasi & Klorofil-a & Suhu Permukaan Laut & Kec. Angin \\
\hline Klorofil-a & 1 & -0.469 & +0.783 \\
SPL & -0.469 & 1 & -0.699 \\
Kec. Angin & +0.783 & -0.699 & 1 \\
\hline
\end{tabular}

Hasil uji korelasi Spearman pada tabel 2 menunjukkan hubungan antara klorofil-a dengan suhu permukaan laut dengan nilai $-0,469$. Nilai korelasi tersebut $(-0,469)$ menunjukkan hubungan yang berbanding terbalik, apabila klorofil-a tinggi maka suhu permukaan laut rendah dan sebaliknya. Hubungan antara klorofil-a dengan kecepatan angin bernilai $+0,783$, nilai ini menunjukkan hubungan yang berbanding lurus. Apabila klorofil-a tinggi maka kecepatan angin juga maksimum dan sebaliknya. Hubungan antara suhu permukaan laut dengan kecepatan angin bernilai $-0,699$, nilai ini menunjukkan hubungan yang berbanding terbalik. Apabila suhu permukaan laut tinggi maka kecepatan angin minimum dan sebaliknya.

\section{C.4. Validasi Upwelling}

Validasi upwelling ini diperlukan untuk melihat hubungan antar parameter khususnya klorofil-a dan suhu permukaan laut pada bulan Juni dan bulan Desember di Perairan Selatan Sumbawa tahun 2018 dengan jumlah duapuluh stasiun pemantauan. Berikut gambar 4 dan gambar 5 yang memperlihatkan hubungan sebaran klorofil-a dan suhu permukaan laut pada dua bulan tersebut (Juni \& Desember).

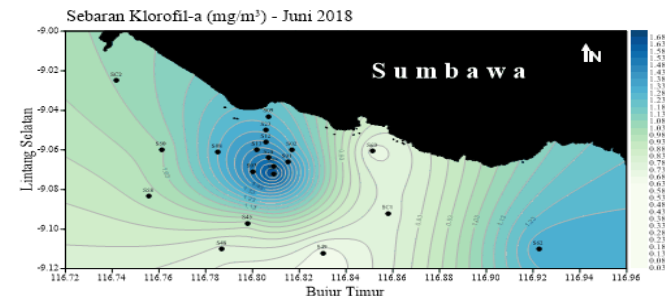

(a)

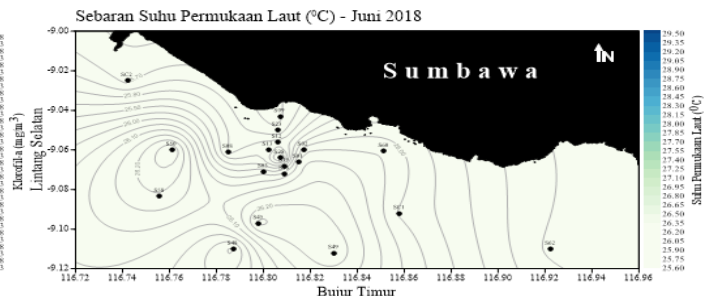

(b)

Gambar 4. Nilai Sebaran Klorofil-a $\left(\mathrm{mg} / \mathrm{m}^{3}\right)$ (a) dan Suhu Permukaan Laut $\left({ }^{0} \mathrm{C}\right)(\mathrm{b})$, 
Juni 2018 Pada gambar 4 memperlihatkan pada bulan Juni nilai sebaran klorofil-a di Perairan Selatan Sumbawa berada pada kisaran $0,65-1,71 \mathrm{mg} / \mathrm{m}^{3}$ dan nilai sebaran suhu permukaan laut berada pada kisaran $25,82-26,96{ }^{\circ} \mathrm{C}$. Klorofil-a tertinggi $\left(1,71 \mathrm{mg} / \mathrm{m}^{3}\right)$ dengan suhu permukaan laut $25,98{ }^{\circ} \mathrm{C}$ terlihat di stasiun S16 dan sekitarnya, serta terlihat juga di stasiun S02 dengan nilai klorofil-a sebesar $1,28 \mathrm{mg} / \mathrm{m}^{3}$ dengan suhu permukaan laut $26,04{ }^{0} \mathrm{C}$, kondisi ini juga terlihat hingga pesisir pantai (S09). Sedangkan klorofil-a terendah $\left(0,65 \mathrm{mg} / \mathrm{m}^{3}\right)$ dengan suhu permukaan laut $26,46{ }^{\circ} \mathrm{C}$ ditemukan di stasiun S49 yang berada menjauh ke arah Selatan dari S16. Gambar 5 di bawah memperlihatkan nilai sebaran klorofil-a pada bulan Desember berada pada kisaran 0,04 $0,30 \mathrm{mg} / \mathrm{m}^{3}$ dan suhu permukaan laut $28,69-29,17^{\circ} \mathrm{C}$.

(a)

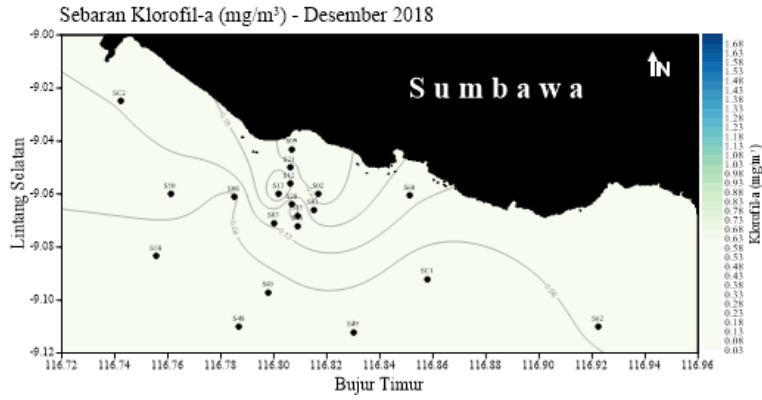

(b)

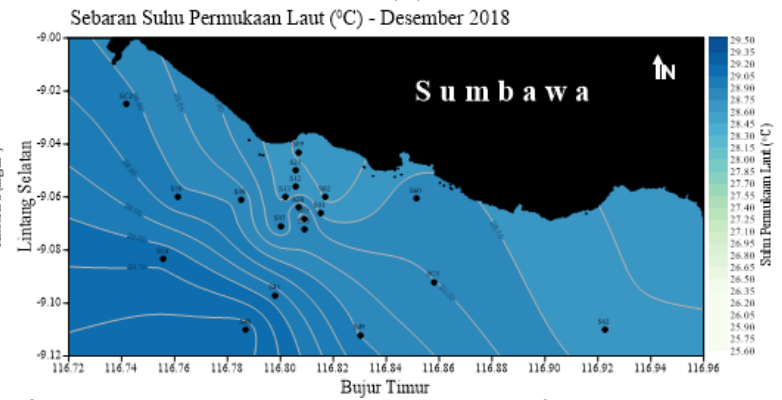

Gambar 5. Nilai Sebaran Klorofil-a $\left(\mathrm{mg} / \mathrm{m}^{3}\right)$ (a) dan Suhu Permukaan Laut $\left({ }^{0} \mathrm{C}\right)(\mathrm{b})$,

Desember 2018

Pada gambar 5 nilai klorofil-a tertinggi $\left(0,30 \mathrm{mg} / \mathrm{m}^{3}\right)$ dengan suhu permukaan laut sebesar $28,73{ }^{0} \mathrm{C}$ terlihat di stasiun S13 dan sekitarnya, sedangkan klorofil-a terendah $\left(0,04 \mathrm{mg} / \mathrm{m}^{3}\right)$ dengan suhu permukaan laut sebesar $28,80{ }^{\circ} \mathrm{C}$ terlihat di stasiun SC1 yang berada menjauh ke arah Tenggara dari S13. Nilai sebaran klorofil-a pada bulan Desember jauh lebih rendah $\left(0,30 \mathrm{mg} / \mathrm{m}^{3}\right)$ jika dibandingkan dengan nilai sebaran klorofil-a pada bulan Juni $1,71 \mathrm{mg} / \mathrm{m}^{3}$, sedangkan nilai sebaran suhu permukaan laut pada bulan Desember jauh lebih tinggi $\left(29,17^{\circ} \mathrm{C}\right)$ jika dibandingkan dengan nilai sebaran suhu permukaan laut pada bulan Juni $26,96{ }^{\circ} \mathrm{C}$. Berdasarkan gambar 4 dan gambar 5 di atas menunjukkan perbedaan yang cukup signifikan dimana fenomena upwelling sangat kuat terjadi pada bulan Juni di stasiun S16 dan sekitarnya (S28) hingga pesisir pantai (S09). Sedangkan downwelling terjadi pada bulan Desember di stasiun SC1 dan sekitarnya yang berada menjauh ke arah Tenggara dari S13.

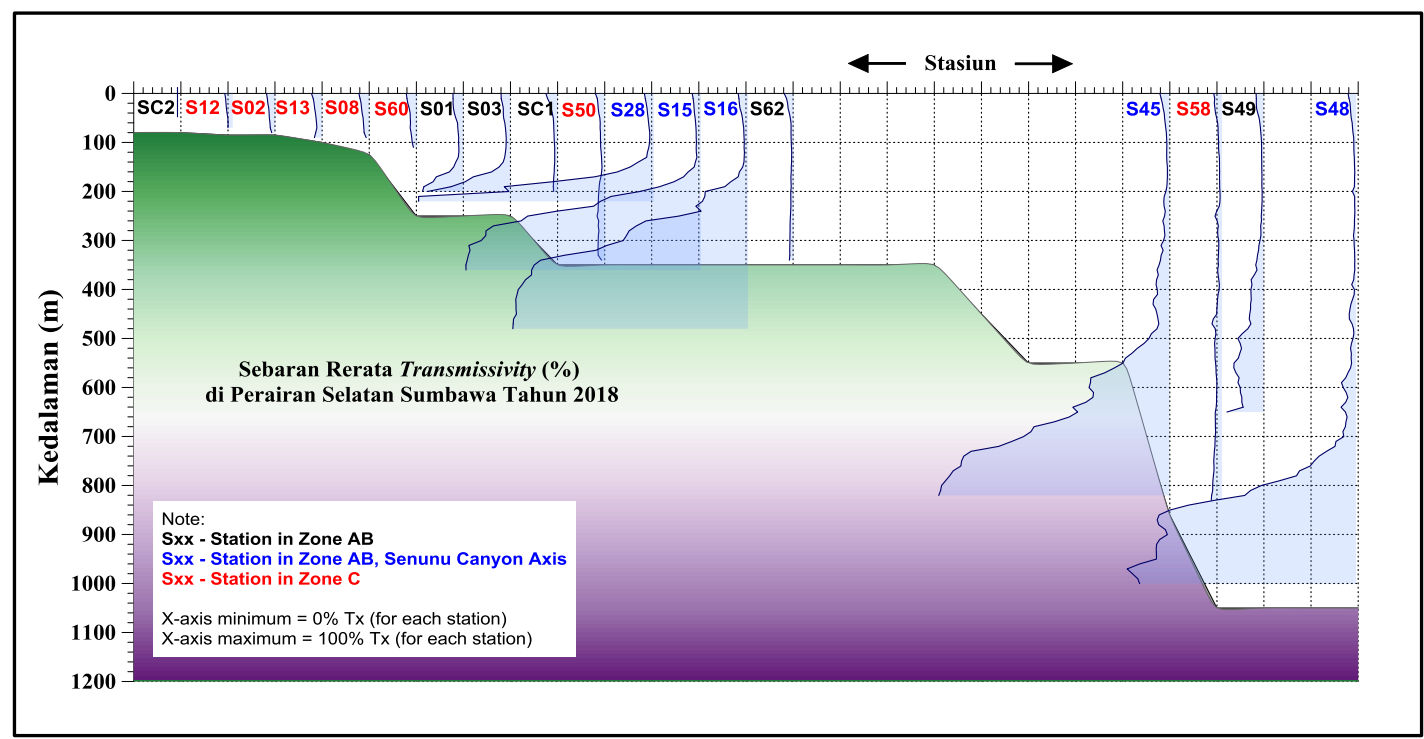

Gambar 6. Sebaran Rata-rata Transmissivity (\%) di Perairan Selatan Sumbawa Tahun 2018

Selama periode upwelling yang telah dijelaskan di atas, sisa batuan alami yang dihasilkan oleh PTAMNT berupa tailing yang ditempatkan pada kedalaman $125 \mathrm{~m}$ dari permukaan laut tidak 
memperlihatkan adanya indikasi atau muncul ke lapisan permukaan. Hal tersebut dapat terlihat jelas dari rerata nilai transmissivity pada gambar 6 di atas.

Transmissivity atau transmisivitas adalah persentase (\%) tingkat kecerahan atau kejernihan suatu perairan, dimana semakin tinggi kecerahan atau kejernihan suatu perairan maka semakin banyak cahaya yang dapat menembus ke dalam badan air. Peralatan yang digunakan untuk mengukur tingkat kejernihan atau kecerahan tersebut bernama Transmissometer yang terpasang dan terintegrasi pada alat ukur CTD.

Gambar 6 di atas menunjukkan bahwa rerata nilai transmisivitas di Perairan Selatan Sumbawa khususnya di sekitar penempatan tailing PTAMNT berada pada kisaran 95 - 100\% dengan kedalaman 0 - $125 \mathrm{~m}$. Hal ini membuktikan bahwa tailing PTAMNT yang ditempatkan di kedalaman $125 \mathrm{~m}$ dari permukaan air laut tidak naik atau tidak muncul ke lapisan permukaan selama periode upwelling. Tailing PTAMNT yang tidak muncul ke lapisan permukaan selama periode upwelling dikarenakan adanya lapisan termoklin yang menghalangi massa air di lapisan bawah untuk naik ke lapisan yang berada di atasnya.

\section{KESIMPULAN}

Hasil analisis pola sebaran klorofil-a, suhu permukaan laut dan angin di Perairan Selatan Sumbawa khususnya di sekitar penempatan tailing PTAMNT selama tahun 2018 dapat disimpulkan sebagai berikut :

1. Kriteria upwelling berdasarkan SPL pada bulan Januari hingga April menunjukkan kriteria upwelling menengah, bulan Mei menujukkan kriteria upwelling kuat dan kriteria upwelling sangat kuat terjadi pada bulan Juni hingga September dengan puncak kekuatan kriteria upwelling tertinggi terjadi pada bulan Juli (SPL terendah, 25,64 ${ }^{\circ} \mathrm{C}$, kecepatan angin mencapai nilai maksimum $3,12 \mathrm{~m} / \mathrm{s}$ ). Namun saat memasuki bulan Oktober, kriteria upwelling mengalami penurunan menjadi kriteria upwelling kuat hingga downwelling yang terjadi pada bulan Desember (SPL tertinggi, $28,84{ }^{\circ} \mathrm{C}$, kecepatan angin relatif rendah sebesar $1,58 \mathrm{~m} / \mathrm{s}$ ).

2. Kriteria upwelling berdasarkan klorofil-a pada bulan Januari hingga Februari menunjukkan kriteria downwelling, bulan Maret menujukkan kriteria upwelling kuat dan kriteria upwelling sangat kuat terjadi pada bulan April hingga Juni dengan puncak kekuatan kriteria upwelling tertinggi terjadi pada bulan Juni (klorofil-a tertinggi, $1,01 \mathrm{mg} / \mathrm{m}^{3}$ ). Namun saat memasuki bulan Juli, kriteria upwelling mengalami penurunan menjadi kriteria upwelling kuat hingga kriteria downwelling yang terjadi pada bulan Desember (klorofil-a terendah, $\left.0,14 \mathrm{mg} / \mathrm{m}^{3}\right)$.

3. Fenomena upwelling sangat kuat terjadi pada musim timur pada bulan Juni di Perairan Selatan Sumbawa tepatnya di stasiun S16 yang ditandai dengan banyaknya atau tingginya kandungan klorofil-a sebesar $1,71 \mathrm{mg} / \mathrm{m}^{3}$. Sedangkan downwelling terjadi pada musim barat pada bulan Desember di Perairan Selatan Sumbawa tepatnya di stasiun SC1 yang ditandai dengan rendahnya kandungan klorofil-a sebesar $0,04 \mathrm{mg} / \mathrm{m}^{3}$.

4. Hasil studi ini juga menunjukan bahwa selama periode upwelling di Perairan Selatan Sumbawa khususnya di sekitar penempatan tailing PTAMNT tidak memperlihatkan adanya indikasi naiknya atau munculnya tailing ke lapisan permukaan.

\section{UCAPAN TERIMA KASIH}

Terwujudnya studi ini tidak lepas dari partisipasi dan bantuan dari berbagai pihak. Oleh karena itu, penulis ingin menyampaikan terima kasih yang sebesar-besarnya kepada :

1. Bapak Wudi Raharjo selaku General Manager Operation PTAMNT

2. Bapak Pradono Parama Prasta selaku Legal Council PTAMNT

3. Ibu Anita Avianty selaku Sr. Manager Corporate Communication PTAMNT 
4. Bapak Raymond Boyska selaku Sr. Manager SHE Department PTAMNT

5. Ibu Jorina Waworuntu selaku Manager Environmental Department PTAMNT

6. Bapak Windy Prayogo selaku Superintendent Environmental Monitoring PTAMNT

7. Seluruh tim Environmental Monitoring section PTAMNT

8. Seluruh tim Kapal Tenggara Ranger

\section{DAFTAR PUSTAKA}

B. Hasyim, (2014), "Identifikasi Zona Potensi Penangkapan Ikan di Selat Madura waktu El Nino Berdasarkan Data Penginderaan Jauh”, Seminar Nasional Penginderaan Jauh, 2.

Kunarso, (2014) "Pengaruh Monsun, El Nino Southern Oscillation \& Indian Ocean Dipole Terhadap Waktu \& Daerah Penangkapan Ikan Tuna di Samudera Hindia Bagian Timur"

Raharjo, S. (2015), data diperoleh dari situs https://www.konsistensi.com/2015/02/uji-koefisienkorelasi-spearman-dengan.html?m=1 
